\title{
Lumpy skin disease in Kazakhstan
}

\author{
Mukhit B. Orynbayev $^{1,2}$ (D) Raikhan K. Nissanova ${ }^{1,3} \cdot$ Berik M. Khairullin $^{1} \cdot$ Arman Issimov $^{1,4} \cdot$ Kunsulu D. Zakarya ${ }^{1}$. \\ Kulyaisan T. Sultankulova ${ }^{1}$ • Lespek B. Kutumbetov ${ }^{1}$ - Ali B. Tulendibayev ${ }^{1}$ - Balzhan Sh. Myrzakhmetova ${ }^{1}$. \\ Erbol D. Burashev ${ }^{1} \cdot$ Sergazy S. Nurabayev ${ }^{1} \cdot$ Olga V. Chervyakova $^{1} \cdot$ Aziz K. Nakhanov $^{1} \cdot$ Richard A. Kock $^{5}$
}

Received: 9 June 2020 / Accepted: 8 February 2021/Published online: 15 February 2021

(C) The Author(s) 2021

\begin{abstract}
This study describes the registration of the first cases of lumpy skin disease in July 2016 in the Republic of Kazakhstan. In the rural district of Makash, Kurmangazinsky district of Atyrau region, 459 cattle fell ill and 34 died (morbidity 12.9\% and mortality $0.96 \%$ ). To determine the cause of the disease, samples were taken from sick and dead animals, as well as from insects and ticks. LSDV DNA was detected by PCR in all samples from dead animals and ticks (Dermacentor marginatus and Hyalomma asiaticum), in $14.29 \%$ of samples from horseflies (Tabanus bromius), and in one of the samples from two Stomoxys calcitrans flies. The reproductive LSD virus was isolated from organs of dead cattle and insects in the culture of LT and MDBK cells. The virus accumulated in cell cultures of LT and MDBK at the level of the third passage with titers in the range of 5.5-5.75 $\log 10$ TCID50 $/ \mathrm{cm}^{3}$. Sequencing of the GPCR gene allowed us to identify this virus as a lumpy skin disease virus.
\end{abstract}

Keywords Lumpy skin disease $\cdot$ Kazakhstan $\cdot$ Vector-borne disease $\cdot$ Tick $\cdot$ Insect

\section{Introduction}

Lumpy skin disease (LSD) mainly infects cattle and is characterized by fever, lymphadenitis, edema of subcutaneous cellular tissue and viscera, cutaneous nodules (lumps), ocular discharge, and inflammation of the mucosae (Prozesky and Barnard 1982). It is a transmissible disease that is transferred by various arthropods (Chihota et al. 2003) and causes significant economic losses because of cattle exhaustion, hide

Mukhit B. Orynbayev

omb65@mail.ru

1 RGE 'Research Institute for Biological Safety Problems', Committee of Science, The Ministry of Education and Science of the Republic of Kazakhstan, Gvardeiskiy, Zhambyl Region, Republic of Kazakhstan

2 Kazakh National Agrarian University, Almaty 050010, Republic of Kazakhstan

3 Kyrgyz National Agrarian University named after K.I.Skryabin, Bishkek, Kyrgyzstan

4 Sydney School of Veterinary Science, Faculty of Science, University of Sydney, Sydney, Australia

5 Pathobiology and Population Sciences, Royal Veterinary College, Hawkshead Lane Herts AL9 7TA, UK damage, infertility, mastitis, and reduced milk production and up to $20 \%$ mortality is reported (Shalaby et al. 2016). LSD has been reported in other domestic species and wildlife naturally and through experimental infection (Young et al. 1970; Usadov et al. 2018; EFSA (European Food Safety Authority). 2015; Greth et al. 1992). LSD antibody has been detected in many species (Hedger and Hamblin 1983; Barnard 1997; Coetzer 2004) but these might also include reaction to other capripoxviruses (Davies 1982; Hamblin et al. 1990).

The causative agent of lumpy skin disease is a DNAcontaining virus of the Capripoxvirus genus, Poxviridae family (Tulman et al. 2001). The Capripoxvirus genus consists of three members: sheep pox (SPPV), goat pox (GTPV), and lumpy skin disease (LSDV).

The lumpy skin disease virus (LSDV) was identified as the etiological agent for the condition in the 1940s rather than due to hypersensitivity to insect bites or plant poisoning as previously described (Macdonald 1931; Von Backstrom 1945). LSD was apparently confined to Africa until the 1980s when it emerged in the Middle East and Near Eastern countries (Wainwright et al. 2013). In 2014 and 2016, the disease spread to Europe and after being first registered in 2014 in Azerbaijan (Zeynalova et al. 2016) spread into Russia (EFSA (European Food Safety Authority) 2017). From there, it spread to the Northern Caucasus (Salnikov et al. 2018; Sprygin et al. 
$2018 \mathrm{a}, \mathrm{b})$. According to the data of the Information and Analytical Department of the Rosselkhoznadzor in the Russian Federation, during years 2016-2017, LSD outbreaks were registered in the Republic of Dagestan, in the Republic of in Bashkortostan, as well as on the Kazakhstan neighboring territories (Volgograd, Saratov, Samara, Astrakhan and Orenburg regions) (Rosselkhoznadzor 2017).

LSD emergence in northwestern Kazakhstan is likely to have serious consequences. The livestock industry is reemerging including the legalization of pastoral livestock livelihoods once banned during the Soviet period. In addition, the region is inhabited by significant numbers of potentially susceptible wild animals including the critically endangered saiga antelope (Saiga tatarica tatarica), which Kazakhstan protects, and this population constitutes the major part of the remaining global population of this species. Various species of endemic insects and ticks occur in the steppe which might constitute a permanent vector, while the wide temperature variations may restrict the potential for vector competence and completion of the life cycles of the virus in this region.

Our investigation aimed at clarifying the cause of a disease outbreak in animals in the Atyrau region in 2016, as well as on presumptive diagnosis of LSD assessing the level of infection among various species of insects and ticks in an outbreak area. In this article, we describe the first confirmed cases of LSD in Kazakhstan in 2016, earlier reported as LSD based on clinical evidence alone to the OIE (WAHIS 2021). The paper reports in full the diagnostic and control methods used and preventive measures taken to reduce further spread of LSD in the country

\section{Materials and methods}

\section{LSD affected areas and cattle populations}

In late June and early July 2016, an outbreak of a disease of unknown etiology was observed in the village Makash in the Kurmaganzinsky district of the Atyrau region, located $50 \mathrm{~km}$ from the border with Russia. The first cases of the disease reported on June 30, 2016, in 5 animals in the village of Makash. The animals showed depression, inappetence, fever of $40{ }^{\circ} \mathrm{C}$, nodule formation on the skin in various parts of the body ranging in size from 0.5 to $3 \mathrm{~cm}$, serous discharge from the eyes, and increased salivation (Fig. 1). Reports of an unknown disease in the rural district continued. As of July 7 , 2016, clinical signs of the unknown disease were detected in 78 cattle from the Makash rural district, and by July 21, 2016, when the disease was notified to the OIE, 459 cattle had fallen ill and 34 died (disease prevalence was $12.9 \%$ and mortality $0.96 \%)$.

In the Kurmangazinsky district, all the livestock is privately owned by citizens who keep animals in 7 livestock enterprises and several peasant farms. The farm and pasture of peasant farms are located separately from the settlements and each of them has more than a hundred heads of cattle. In total, in 2016 Kurmangazinsky district of Atyrau Province recorded 49,000 cattle, kept in 1,042 yards and farms 3,557 cattle were kept in 69 yards and farms of the Makash rural district. All settlements affected with clinical lumpy skin disease concentrated in the basin and flood plain of the Volga River running to the Caspian Sea. Located in a densely populated region along the highway and railway from Atyrau towards the Russian Federation. The Kurmangazinsky district of the Atyrau Province in the west borders on the Krasnoyarsk district of the Astrakhan Province of Russia, in the north with the Bokeyordinsky district of the West Kazakhstan region, and in the east with the Isatai district of the Atyrau Province. The territory of the Kurmangazinsky district is 20.8 thousand square kilometers, which is crossed by many rivers; the largest is the Kigach River.

\section{Sampling and preparation of tissues for virus detection}

The Research Institute for Biological Safety Problems (RIBSP) sent an investigative mission to the region to further research the disease and samples were collected in July 2016 at a farm of the Kurmaganzy district of Atyrau Province during an outbreak of a disease with unknown etiology.

Biological samples from animals with clinical signs of the disease were also collected by state veterinarians as part of routine epidemiological surveillance. RIBSP investigators attended at the sampling. For studies, blood samples were taken from five sick cows and nine samples of internal organs (lymph nodes, spleen, lungs, skin with nodular lesions) from two dead cows. In addition to this, 13 ticks were collected from infected cattle and 21 horseflies and two biting flies were collected in the infection locus using Vavoua traps (Mihok et al. 1995). Detailed information on the collected specimens is shown in Table 1. All collected samples were preserved in liquid nitrogen and delivered to the Class III biological safety laboratory (RIBSP) in Gvardeskiy for diagnosis.

\section{Collection and preparation of samples}

Preparation of samples was carried out according to the procedure described in chapter 1.1 Specimen collection, submission and preparation, OIE Terrestrial Manual 2018.

\section{Preparing arthropods for research}

Ticks (Dermacentor marginatus and Hyalomma asiaticum), horseflies (Tabanus bromius), and flies (Stomoxys calcitrans) collected in the field were transported to the laboratory and then were washed one time in ethanol and two times in sterile 
Fig. 1 Clinical signs of lumpy skin disease
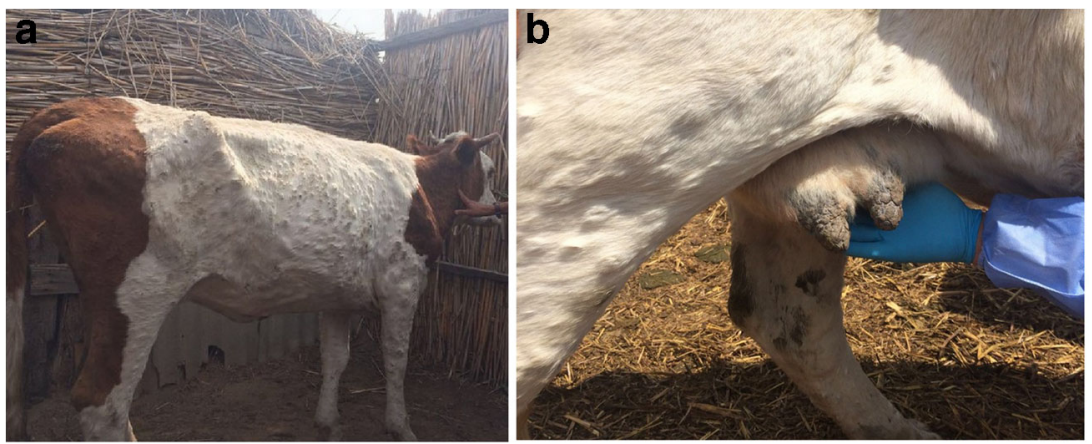

phosphate-buffered saline (PBS) with (penicillin $500 \mathrm{IU} / \mathrm{ml}$, streptomycin $1 \mathrm{mg} / \mathrm{ml}$, mycostatin $100 \mathrm{IU} / \mathrm{ml})$. Each insect was transferred to a small chilled porcelain mortar and ground. To prepare the suspension, $0.3 \mathrm{ml}$ of PBS solution with antibiotics (penicillin and streptomycin, 100-200 IU/ml) was added. The suspension was frozen and thawed three times, and then clarified by centrifugation at $600 \mathrm{~g}$ for $10 \mathrm{~min}$. The supernatant was used for the study. Pools were prepared from several individuals of the same arthropod species for virus isolation.

\section{Virus isolation in cell culture}

Virus isolation was performed as described in chapter 1.2 Virus isolation in cell culture, OIE Terrestrial Manual 2018. Primary lamb testicle (LT) cell culture and MDBK cell line were used. One $\mathrm{ml}$ of clarified supernatant or blood was inoculated to a confluent monolayer in a $25 \mathrm{~cm}^{2}$ culture flask at 37 ${ }^{\circ} \mathrm{C}$ and allowed to adsorb for $1 \mathrm{~h}$. The culture was washed with warm PBS and filled with $10 \mathrm{ml}$ of antibiotic-containing DMEM medium (penicillin $100 \mathrm{IU} / \mathrm{ml}$, streptomycin 0.1 $\mathrm{mg} / \mathrm{ml}$ ) and $2 \%$ fetal calf serum.
The flasks were checked daily during 7-10 days for cytopathic effects (CPE). If no CPE was observed by day 10, the culture was frozen three times, and the clarified supernatant was inoculated into fresh LT or MDBK culture. The specificity of the CPE was confirmed by PCR.

\section{DNA extraction}

DNA was extracted from supernatant, blood, and culture suspension using the "DNeasy® Blood \& Tissue Kit (250)", QIAGEN, following the manufacturer's protocol.

\section{PCR implementation}

PCR was performed to confirm the presence of LSDV specific nucleic acid using a pair of primers: forward primer, $5^{\prime}$ TTTCCTGATTTTTCTTACTAT-3' and reverse primer, 5'AAATTATATACG TAAATAAC-3' (El-Nahas et al. 2011). The reaction mixture contained $25 \mu \mathrm{L} 2 \times$ AmpliTaq Gold (Applied Biosystems) buffers, $1 \mu \mathrm{L}$ each of 20 -pM primers, $1 \mu \mathrm{L}$ of DNA, and up to $50 \mu \mathrm{L}$ of water. Amplification modes were as follows: initial denaturation at $95^{\circ} \mathrm{C}$ for $5 \mathrm{~min}$, denaturation at $94{ }^{\circ} \mathrm{C}$ for $45 \mathrm{~s}$, annealing at $56-60{ }^{\circ} \mathrm{C}$ for $45 \mathrm{~s}$,

Table 1 The results of PCR studies and virus isolation in LT cell culture

\begin{tabular}{|c|c|c|c|c|c|c|c|c|}
\hline \multirow[t]{2}{*}{ No. } & \multirow[t]{2}{*}{ Sample } & \multirow{2}{*}{$\begin{array}{l}\text { PCR } \\
\text { tested/ } \\
\text { positive }\end{array}$} & \multicolumn{6}{|c|}{ Virus isolation } \\
\hline & & & $\begin{array}{l}1 \text { passage } \\
\text { tested/ } \\
\text { isolated }\end{array}$ & $\begin{array}{l}\text { Time of } \\
\text { appearance } \\
\text { of CPE (d.p.i.) }\end{array}$ & $\begin{array}{l}2 \text { passage } \\
\text { tested/ } \\
\text { isolated }\end{array}$ & $\begin{array}{l}\text { Time of } \\
\text { appearance } \\
\text { of CPE (d.p.i.) }\end{array}$ & $\begin{array}{l}3 \text { passage } \\
\text { tested/ } \\
\text { isolated }\end{array}$ & $\begin{array}{l}\text { Time of } \\
\text { appearance } \\
\text { of CPE (d.p.i.) }\end{array}$ \\
\hline 1 & Lymph node & $2 / 2$ & $2 / 2$ & $\begin{array}{l}\text { №1 (7) } \\
\text { №2 (8) }\end{array}$ & $2 / 2$ & (3) & $2 / 2$ & (2) \\
\hline 2 & Spleen & $2 / 2$ & $2 / 2$ & (8) & $2 / 2$ & (3) & $2 / 2$ & (2) \\
\hline 3 & Lungs & $2 / 2$ & $2 / 2$ & (7) & $2 / 2$ & (3) & $2 / 2$ & (2) \\
\hline 4 & Nodules & $3 / 3$ & $3 / 3$ & (7) & $3 / 3$ & (2) & $3 / 3$ & (2) \\
\hline 5 & Blood of sick cattle & $5 / 5$ & Н.и. & - & Н.и. & - & Н.и. & - \\
\hline 6 & Ticks Dermacentor marginatus & $4 / 4$ & $1 / 0$ & - & $1 / 1$ & №1 (6) & $1 / 1$ & №1 (3) \\
\hline 7 & Ticks Hyalomma asiaticum (Weiss, 1968) & $9 / 9$ & $2 / 0$ & - & $2 / 1$ & №1 (5) & $2 / 2$ & №1 (2)№2 (4) \\
\hline 8 & Horseflies Tabanus bromius & $21 / 3$ & $1 / 0$ & - & $1 / 1$ & №1 (6) & $1 / 1$ & №1 (3) \\
\hline 9 & Flies Stomoxys spp. & $2 / 1$ & $1 / 0$ & - & $1 / 1$ & (7) & $1 / 1$ & (3) \\
\hline
\end{tabular}


replication at $72{ }^{\circ} \mathrm{C}$ for $2 \mathrm{~min}, 35$ cycles, post-replication at 72 ${ }^{\circ} \mathrm{C}$ for $10 \mathrm{~min}$. The size of the resulted amplificons was in line with the expected size of the PCR product (192 bp). The museum strain "Cattle/1986" deposited into the Microbial Collection of the RIBSP served as a positive control.

A second PCR was carried out on all positive samples to amplify the GPCR gene for phylogenetic analysis. This was done using primers designed by Le Goff et al. 2009 (Le Goff et al. 2009).

The DNA amplification of the GPCR gene was performed in a $25 \mu \mathrm{L} 2 \times$ AmpliTaq Gold buffers, $1 \mu \mathrm{L}$ each of 10-pM primers, $1 \mu \mathrm{L}$ of DNA, and up to $50 \mu \mathrm{L}$ of water. The PCR amplification of the GPCR gene involved an initial denaturation at $96^{\circ} \mathrm{C}$ for $5 \mathrm{~min}$ followed by 35 cycles of final denaturation at $95^{\circ} \mathrm{C}$ for $30 \mathrm{~s}$, annealing at $50^{\circ} \mathrm{C}$ for the $30 \mathrm{~s}$, and extension at $72{ }^{\circ} \mathrm{C}$ for $30 \mathrm{~s}$ as previously described.

\section{Sequencing}

Sequencing was conducted by dideoxysequencing with the use of chain-terminating dideoxynucleotides (Sanger technique) in a 16-channel sequencer Genetic Analyzer 3130 xl, Applied Biosystems (USA). POP-7 was used as a polymer for capillaries. The terminating DNA products were generated by the method of cyclic sequencing.

The evolutionary history was inferred using the neighborjoining method (Saitou and Nei 1987). The percentage of replicate trees in which the associated taxa clustered together in the bootstrap test (1000 replicates) are shown next to the branches (Felsenstein 1985). The tree is drawn to scale, with branch lengths in the same units as those of the evolutionary distances used to infer the phylogenetic tree. The evolutionary distances were computed using the Tamura-Nei method (Tamura and Nei 1993) and are in the units of the number of base substitutions per site. Evolutionary analyses were conducted in MEGA7 (Kumar et al. 2016). The analysis involved 32 nucleotide sequences.

\section{Electron microscopy}

To study the morphology of the LSDV the specimens of the pathology material (skin, lumps) from cattle and insects were examined. LSDV preparations were assayed in the electron microscope (JEM $100 \mathrm{~B}$ ) with negative contrasting by $4 \%$ solution of phosphate-tungstic acid, $\mathrm{pH} 6.8$.

\section{Results}

Biological samples from sick and dead animals, ticks and insects in the disease locus were assayed for LSDV. The capripoxvirus DNA was detected by PCR in all tested samples of organs from dead animals and ticks (Dermacentor marginatus and Hyalomma asiaticum), in three specimens (14.29\%) from horseflies (Tabanus bromius), and in one of the specimens from two flies (Stomoxys calcitrans) (Table 1).

Positive specimens were used to infect the primary trypsinized lamb testicle cell cultures (LT) and the continuous bovine kidney cell line (MDBK). Both infected cell cultures demonstrated the presence of the cytopathogenic agent.

A cytopathic effect was detected at the first passage level in LT cell culture after infection with a suspension from all organs (LN, spleen, lungs, nodules) taken from dead animals.

CPE in cell culture infected with a suspension of Dermacentor marginatus, horseflies, and flies (Stomoxys spp.) was observed from the 2 passage level after 6-7 days of cultivation. During infection, the same cell culture with suspensions of Hyalomma asiaticum ticks, only one sample of two used, had a cytopathic effect in the second passage, and the second sample in the third passage. The cytopathogenic effect of the virus in the first passage level usually appeared within 7 to 9 days after infection. In the subsequent passages, these terms were reduced, and at the third passage level, CPE was noted for 2-4 days. Distinct CPE with 75-90\% affection of the cellular layer was demonstrated in these cultures on the third passage level on the 8th day of cultivation.

Suspensions of the internal organs taken from animals post mortem were used for infecting the MDBK cell culture. The cytopathic effect of the virus in this cell culture was detected in the second passage level after 6-7 days of incubation. In the third passage, the timing of the onset of CPE was reduced and noted on the third day with the defeat of $70-80 \%$ of the monolayer cells.

The virus accumulated in these cultures (LT, MDBK) on the third passage level in titers within 5.5-5.75 $\log 10 \mathrm{TCID}_{50} / \mathrm{cm}^{3}$.

The specificity of the isolated viruses was confirmed in PCR and by electron microscopy. In all specimens, an amplification product sized 192 bp typical for the LSDV was generated. The study of the morphology and fine structure of the negatively stained preparations showed viral particles typical for LSDV. The size of the virions varied within $300 \times 370 \mathrm{~nm}$, while the bulk mass of particles $(90 \%)$ was sized $300 \times 350 \mathrm{~nm}$.

A virus isolated from the skin nodules of a dead animal was selected for archiving "Nodulares/Dermatitis/Atyrau-2016" and deposited into the Microbial Collection of the RGE RIBSP, and later this same virus was used to produce an attenuated candidate vaccine strain.

Sequencing of the GPCR gene allowed us to identify this virus as a lumpy skin disease virus.

\section{Disease control}

After the first cases of the disease, in the Kurmangazy region, the veterinary service introduced restrictive measures to localize and eliminate the disease. The movement of all species of domestic animals was prohibited, and a daily farm visit was carried 
out in order to identify animals with clinical signs of lumpy skin disease. After laboratory confirmation of the disease, the affected area (Kurmangazy region) was quarantined. All 459 animals with clinical signs were culled and the owners were compensated at the market value of the animal. Disinfection of affected sites was completed including $28.116 \mathrm{~m}^{2}$ of land. The remaining live animals were treated with repellents.

After confirming the diagnosis and reporting the disease to OIE, all the cattle of the Atyrau Province were vaccinated, as well as animals in the risk zone (threatened zone) of the West Kazakhstan and Aktobe Province. Vaccination was carried out using the lumpivax ${ }^{\circledR}$ vaccine manufactured by the Kenya Veterinary Vaccine Manufacturing Institute (KEVEVAPI).

\section{Discussion}

The lumpy skin disease virus is considered a serious pathogen of transboundary significance (Saegerman et al. 2018). Since about 2015, the disease has spread from African countries through the Near East into Europe, Azerbaijan, and Russia, and caused significant economic losses (Zeynalova et al. 2016; Salnikov et al. 2018; Sprygin et al. 2018a, b; Saegerman et al. 2018). The disease was previously recorded only in tropical and sub-tropical countries. There remain many gaps in knowledge on the establishment of LSD in temperate latitudes, and what role rising environmental temperatures, mediated through vectors, will play in LSD epidemiology. The first cases of the disease were reported in Russia in 2015 and this led to studies regarding potential arthropod carriers of LSDV. Virus DNA was found in 13 species of ixodid ticks (Gazimagomedov et al. 2017), and in 2017, DNA of the virus was detected in Musca domestica L. (Sprygin et al. $2018 \mathrm{a}, \mathrm{b})$. At the same time, the infection prevalence of some of the studied species of ticks reached up to $16.3 \%$ in the epidemic zone (Gazimagomedov et al. 2017).

Disease in Kazakhstan was first reported in early July 2016 in the Kurmangazy district of Atyrau Province. LSD diagnosis from this outbreak is confirmed by the laboratory assays (PCR) of the samples from sick and dead animals, as well as confirmation of the presence of the virus in the arthropods collected in the epidemic focus. The etiological agent was isolated in the primary lamb testicle cell culture and in the continuous cell culture MDBK. Further sequencing of the gene GPCR and the phylogenetic analysis showed the close genetic relationship of the isolated capripoxvirus with a group of LSD viruses including those circulating in the areas of the Russian Federation adjacent to Kazakhstan. Emergence of the disease in the western regions of Kazakhstan from probable transboundary sources was confirmed. According to the information in Russia during May-June 2016, there were 163 LSD suspected foci including three in the Astrakhan region bordering the Atyrau Province of Kazakhstan (Rosselkhoznadzor
2017). Until this time, LSD was considered exotic to Kazakhstan and measures were not taken to prevent or diagnose the disease routinely. Through prompt action, the disease was apparently eliminated through stamping out policy in the epidemic focus in Kazakhstan, and a strategy was developed to prevent further incursions from infected countries. The control strategy is based on vaccination of the entire susceptible livestock in Kazakhstan using lumpivax ${ }^{\circledR}$ vaccine manufactured by Kenya Veterinary Vaccines Production Institute (KEVEVAPI).

The peak activity of blood-sucking insects and ticks in Kazakhstan falls in April and October (Faulde n.d.). The emergence of the disease was coincident with a peak of vector activity, and introduction of LSDV on to the territory of Kazakhstan was likely either through the movement of infected livestock and subsequent transmission of the virus by blood-sucking insects, as reported elsewhere, or through movements of vectors, although the latter is less likely as vector movements are over relatively small distances, flies and mosquitos mostly only a few hundred meters unless wind assisted $[32,36]$. The transmission pathways and epidemiology of LSD are as yet not fully understood. LSDV has been detected in biting flies (Stomoxys and Musca spp), Aedes mosquitoes, in ticks (Rhipicephalus appendiculatis), (Amblyomma hebraeum), and (Rhipicephalus (Boophilus) decolaratus) (Tuppurainen and Oura 2011; Chihota et al. 2001; Last 2017; Issimov et al. 2020). Alexandrov (Alexandrov 2017) reported possible mechanical transmission of the LSD virus by Tabanus spodopterus females during an outbreak in 2016 in Bulgaria (Alexandrov 2017). Later, Sohier et al. (2019) experimentally demonstrated that Haematopota spp. (horseflies) can mechanically transmit the LSD virus (Sohier et al. 2019). In our study, several arthropod species including ixodid ticks (Dermacentor marginatus and Hyalomma asiaticum), horseflies (Tabanus bromius), and other biting flies (Stomoxys calcitrans) collected in the disease focus were assayed as potential transmitters. All tick samples were positive, and a proportion of horse flies and Stomoxys flies (Table 1). The first LSDV isolate in cell culture was obtained from sampled horseflies (Tabanus bromius) collected during the outbreak of the disease. These results support the studies of Sohier et al. (2019), which showed experimentally that horseflies can mechanically transmit LSDV. The mechanical transmission of LSDV by ixodid ticks has been shown by many researchers, but until now, there has been little information on the species of ticks and arthropods which might play a role in the transmission of LSDV. Our studies have shown that all individuals sampled, of both species of ticks collected from the region of the outbreak of the disease, were PCR positive for LSDV, and the virus was isolated from the pool of ticks of both species, through cell culture. The ticks and biting flies recorded here are widespread throughout western Kazakhstan and could become vectors of mechanical transmission of the 
LSDV among domestic and wild animals if the virus is established in the animal population. This opportunistic study contributes to published data on the vector transmission of the disease (Tuppurainen et al. 2011). The persistence of the virus in the region will depend on the completion of life cycles of LSD across a zone with an extreme climate and this possibility needs to be monitored through appropriate surveillance annually.

Studies have shown that a novel cattle disease in the Atyrau Province of Kazakhstan in 2015 was caused by infection with the lumpy skin disease virus. Virus was also detected among arthropod horseflies, biting houseflies, and or ticks suggesting the possibility of these species as vectors of LSD in this region.

\section{Code availability Not applicable.}

Author contribution Orynbayev MB: data analysis, writing the manuscript. Nissanova RK: laboratory analysis. Khairullin BM: data analysis. Issimov A: data analysis. Zakarya K: research supervision. Sultankulova KT: data analysis, writing the manuscript. Kutumbetov LB: research supervision. Tulendibayev AB: laboratory analysis. Myrzakhmetova BSh: laboratory analysis. Burashev YeD: laboratory analysis. Nurabayev SS: fieldwork, laboratory analysis. Chervyakova OV: laboratory analysis. Nakhanov AK: laboratory analysis. Kock RA: data analysis, writing the manuscript.

Funding The study was implemented under the financial support of the Ministry of Education and Science and the Ministry of Agriculture of the Republic of Kazakhstan.

Data availability All data needed to evaluate the conclusions in the paper are present in the paper. Additional data related to this paper may be requested from the authors.

\section{Declarations}

Ethics approval This study was approved by the Committee for Veterinary Control and Surveillance of the Ministry of Agriculture of the Republic of Kazakhstan. All ethics, field, and laboratory studies were reviewed and approved by the appropriate committees of the Research Institute for Biological Safety Problems (RIBSP).

\section{Consent to participate Not applicable.}

\section{Consent for publication Not applicable.}

Conflict of interest The authors declare no competing interests.

Open Access This article is licensed under a Creative Commons Attribution 4.0 International License, which permits use, sharing, adaptation, distribution and reproduction in any medium or format, as long as you give appropriate credit to the original author(s) and the source, provide a link to the Creative Commons licence, and indicate if changes were made. The images or other third party material in this article are included in the article's Creative Commons licence, unless indicated otherwise in a credit line to the material. If material is not included in the article's Creative Commons licence and your intended use is not permitted by statutory regulation or exceeds the permitted use, you will need to obtain permission directly from the copyright holder. To view a copy of this licence, visit http://creativecommons.org/licenses/by/4.0/.

\section{References}

Alexandrov, T. (2017). Lumpy skin disease situation in Europe. Preventive and control measures for an effective control-presentation. 11th Annual Meeting of EPIZONE, 19-21 September, Paris.

Barnard, B.J. (1997). Antibodies against some viruses of domestic animals in southern African wild animals. Onderstepoort Journal of Veterinary Research, 64, 95-110

Chihota, C.M., Rennie, L.F., Kitching, R.P., Mellor, P.S., (2001). Mechanical transmission of lumpy skin disease virus by Aedes aegypti (Diptera: Culicidae). Epidemiology and Infection, 126(2), 317-321. https://doi.org/10.1017/S0950268801005179

Chihota, C.M. Rennie, L.F., Kitching, R.P., Mellor, P.S., (2003). Attempted mechanical transmission of lumpy skin disease virus by biting insects. Medical and Veterinary Entomology, 17(3), 294-300. https://doi.org/10.1046/j.1365-2915.2003.00445.x

Coetzer, J.A.W. (2004). Lumpy skin disease. In J. A. W. Coetzer, \& R. C. Tustin (Eds.). Infectious diseases of livestock. 2nd ed. pp. 12681276. Cape Town, South Africa: Oxford University Press.

Davies, F.G. (1982), Observations on the epidemiology of lumpy skin disease in Kenya. The Journal of hygiene, 88(1), 95-102. https://doi. org/10.1017/s002217240006993x

EFSA (European Food Safety Authority). (2017). Scientific report on lumpy skin disease: I. Data collection and analysis. EFSA Journal, 15(4), 4773, 54 pp. doi: https://doi.org/10.2903/j.efsa.2017.4773

EFSA (European Food Safety Authority). (2015). Scientific opinion on lumpy skin disease. EFSA Journal, 13(1), 3986.

El-Nahas, E.M., El-Habbaa, A.S., El-bagoury, G.F., Radwan, M.E.I. (2011). Isolation and Identification of Lumpy Skin Disease Virus from Naturally Infected Buffaloes at Kaluobia, Egypt. Global Veterinaria, 7, 234-237

Faulde, M.K. (n.d.) Vector-borne Infectious Diseases in Kazakhstan https://www.acq.osd.mil/eie/afpmb/docs/dveps/Kazakhstan.pdf

Felsenstein, J. (1985). Confidence limits on phylogenies: An approach using the bootstrap. Evolution, 39, 783-791

Gazimagomedov, M., Kabardiev, S., Bittirov, A., Abdulmagomedov, S., Ustarov, R., Musaev, Z., Bittirova, A. (2017). Specific composition of Ixodidae ticks and their role in transmission of nodular dermatitis virus among cattle in the North Caucasus. The 18th Scientific Conference Theory and Practice of the Struggle Against Parasite Animal Diseases- Compendium 18, 107-110

Greth, A., Gourreau, J.M., Vassart, M., Nguyen-Ba-Vy Wyyers, M., Lefevre, P.C. (1992). Capripoxvirus disease in an Arabian Oryx (Oryx leucoryx) from Saudi Arabia. Journal of Wildlife Diseases, 28, 295-300. https://doi.org/10.7589/0090-3558-28.2.295

Hamblin, C., Anderson, E.C., Jago, M., Mlengeya, T., Hipji, K. (1990), Antibodies to some pathogenic agents in free-living wild species in Tanzania. Epidemiology and Infection, 105(3), 585-94. doi: https:// doi.org/10.1017/s0950268800048226.

Hedger, R.S. and Hamblin, C. (1983). Neutralising antibodies to lumpy skin disease virus in African wildlife. Comparative Immunology, Microbiology and Infectious Diseases, 6, 209-213. https://doi.org/ 10.1016/0147-9571(83)90012-7

Issimov, A., Kutumbetov, L., Orynbayev, M., Khairullin, B., Sultankulova, K., Myrzakhmetova, B., White, P.J. (2020). Mechanical transmission of lumpy skin disease virus by stomoxys spp (stomoxys calsitrans, stomoxys sitiens, stomoxys indica), diptera: muscidae. Animals, 10, 477; doi:https://doi.org/10.3390/ ani10030477 
Kumar, S., Stecher, G. and Tamura, K. (2016). MEGA7: Molecular Evolutionary Genetics Analysis version 7.0 for bigger datasets. Molecular Biology and Evolution, 33, 1870-1874.

Last, R.D. (2017). Lumpy Skin Disease of Springbok. CPD Articles, Hooo-Hooo, Vol 11 No 4,

Le Goff, C., Lamien, C.E., Fakhfakh, E., Chadeyras, A., Abu-Adulugba, E., Libeau, G., Tuppurainen, E., Wallace, D.B., Adam, T., Silber, R., Gulyaz, V., Madani, H., Caufour, P., Hammami, S., Diallo, A., Albina, E. (2009). Capripoxvirus G-protein-coupled chemokine receptor: A host-range gene suitable for virus animal origin discrimination. Journal of General Virology, 90, 1967-77

Macdonald, R.A.S. (1931). Pseudo-Urticaria of Cattle. Northern Rhodesian Department of Health Annual Report. 20-21

Mihok, S., Kang'ethe E.K., Kamau, G.K. (1995). Trials of Traps and Attractants for Stomoxys spp. (Diptera: Muscidae). Journal of Medical Entomology, 32(3), 283-289. doi:https://doi.org/10.1093/ jmedent/32.3.283

Prozesky, L., Barnard, B.J.H. (1982). A study of the pathology of lumpy skin disease in cattle. Onderstepoort Journal of Veterinary Research, 49, 167-75.

Rosselkhoznadzor. LSD-infected regions of RF in 2017. http://fsvps.ru

Saegerman, C., Bertagnoli, S., Meyer, G., Ganière, J.P., Caufour, P., De Clercq, K., Casal, J. (2018). Risk of introduction of lumpy skin disease in France by the import of vectors in animal trucks. PLoS ONE. 13(6): e0198506. https://doi.org/10.1371/journal.pone. 0198506

Saitou, N. and Nei, M. (1987). The neighbor-joining method: A new method for reconstructing phylogenetic trees. Molecular Biology and Evolution, 4, 406-425

Salnikov, N., Usadov, T., Kolcov, A., Zhivoderov, S., Morgunov, Y., Gerasimov, V., Gogin, A., Titov, I., Yurkov, S., Malogolovkin, A., Kolbasov, D., Lunitsyn, A. (2018). Identification and characterization of lumpy skin disease virus isolated from cattle in the Republic of North Ossetia Alania in 2015. Transboundary and Emerging Diseases, 00:1-5. https://doi.org/10.1111/tbed.12818

Shalaby, M.A., El-Deeb, A., El-Tholoth, M., Hoffmann, D., Czerny, C.P., Hufert, F.T., Abd El Wahed, A. (2016). Recombinase polymerase amplification assay for rapid detection of lumpy skin disease virus. BMC Veterinary Research, 12(1), 244. https://doi.org/10. 1186/s12917-016-0875-5

Sohier, C., Haegeman, A., Mostin, L., De Leeuw, I., VanCampe, W., DeVleeschauwer, A., Tuppurainen, E.S., van den Berg, T., De Regge, N., DeClercq, K. (2019). Experimental evidence of mechanical lumpy skin disease virus transmission by Stomoxys calcitrans biting fies and Haematopota spp. Horseflies. Scientific Reports, 9, 20076 https://doi.org/10.1038/s41598-019-56605-6

Sprygin, A., Artyuchova, E., Babin, Y., Prutnikov, P., Kostrova, E., Byadovskaya, O., Kononov, A. (2018a). Epidemiological characterization of lumpy skin disease outbreaks in Russia in 2016. Transboundary and Emerging Diseases, 00:1-8. https://doi.org/ 10.1111/tbed.12889
Sprygin, A., Pestova, Y., Prutnikov, P., Kononov, A. (2018b). Detection of vaccine-like lumpy skin disease virus in cattle and Musca domestica L. flies in an outbreak of lumpy skin disease in Russia in 2017. Transboundary and Emerging Diseases, 00:1-8. https:// doi.org/10.1111/tbed.12897

Tamura, K. and Nei, M. (1993). Estimation of the number of nucleotide substitutions in the control region of mitochondrial DNA in humans and chimpanzees. Molecular Biology and Evolution, 10, 512-526

Tulman, E.R., Afonso, C.L., Lu, Z., Kutish, G.F., Rock, D.L. (2001). Genome of lumpy skin disease virus. Journal of Virology, p. 7122-7130 DOI: https://doi.org/10.1128/JVI.75.15.7122-7130. 2001

Tuppurainen, E. and Oura, C. (2011). Review: Lumpy Skin Disease: An Emerging Threat to Europe, the Middle East and Asia. Transboundary and Emerging Diseases, 59, 40-8. https://doi.org/ 10.1111/j.1865-1682.2011.01242.x.

Tuppurainen, E.S.M., Stoltsz, W.H., Troskie, M., Wallace, D.B., Oura, C.A.L., Mellor, P.S., Venter, E.H. (2011). A Potential Role for Ixodid (Hard) Tick Vectors in the Transmission of Lumpy Skin Disease Virus in Cattle. Transboundary and Emerging Diseases, 58(2), 93-104. https://doi.org/10.1111/j.1865-1682.2010.01184.x

Usadov, T.R., Morgunov, Yu.P., Zhivoderov, S.P., Balysheva, V.I., Pivov A, E. Yu, Koltsov, A. Yu, Yanzhieva, D.V., Sukher, M.M., Lunitsyn, A.V., Salnikov, N.I. (2018). Lumpy skin disease virus, isolated in 2015 in Russia from cattle, is pathogenic for sheep at experimental infection. Sel'skokhozyaistvennaya biologiya [Agricultural Biology], 53, 2, 438-446

Von Backstrom, U. (1945). Ngamiland cattle disease: preliminary report on a new disease, the etiological agent being probably of an infectious nature. Journal of South African Veterinary Medical Association, 16, 29-35

Wainwright, S., El Idrissi, A., Mattioli, R., Tibbo, M., Njeumi, F., Raizman, E. (2013). Emergence of lumpy skin disease in the Eastern Mediterranean Basin countries. FAO Empres Watch, 29, $1-6$

World Animal Health Information Database (WAHIS Interface) (2021) Lumpy skin disease, Kazakhstan, - Version 1. https:// www.oie.int/wahis_2/public/wahid.php/Reviewreport/Review/ viewsummary?reportid=20520. Accessed 15 Feb 2021

Young, E., Basson, P.A., Weiss, K.E. (1970). Experimental infection of game animals with lumpy skin disease virus (prototype strain Neethling). Onderstepoort Journal of Veterinary Research, 37(2), 79-87.

Zeynalova, S., Asadov, K., Guliyev, F., Vatani, M., Aliyev, V. (2016). Epizootology and molecular diagnosis of lumpy skin disease among livestock in Azerbaijan. Frontiers in Microbiology, 7, 1022. https:// doi.org/10.3389/fmicb.2016.01022

Publisher's note Springer Nature remains neutral with regard to jurisdictional claims in published maps and institutional affiliations. 